\title{
Vertebral artery dissection causing an acute C5 radiculopathy
}

Figure Radiology and clinical images

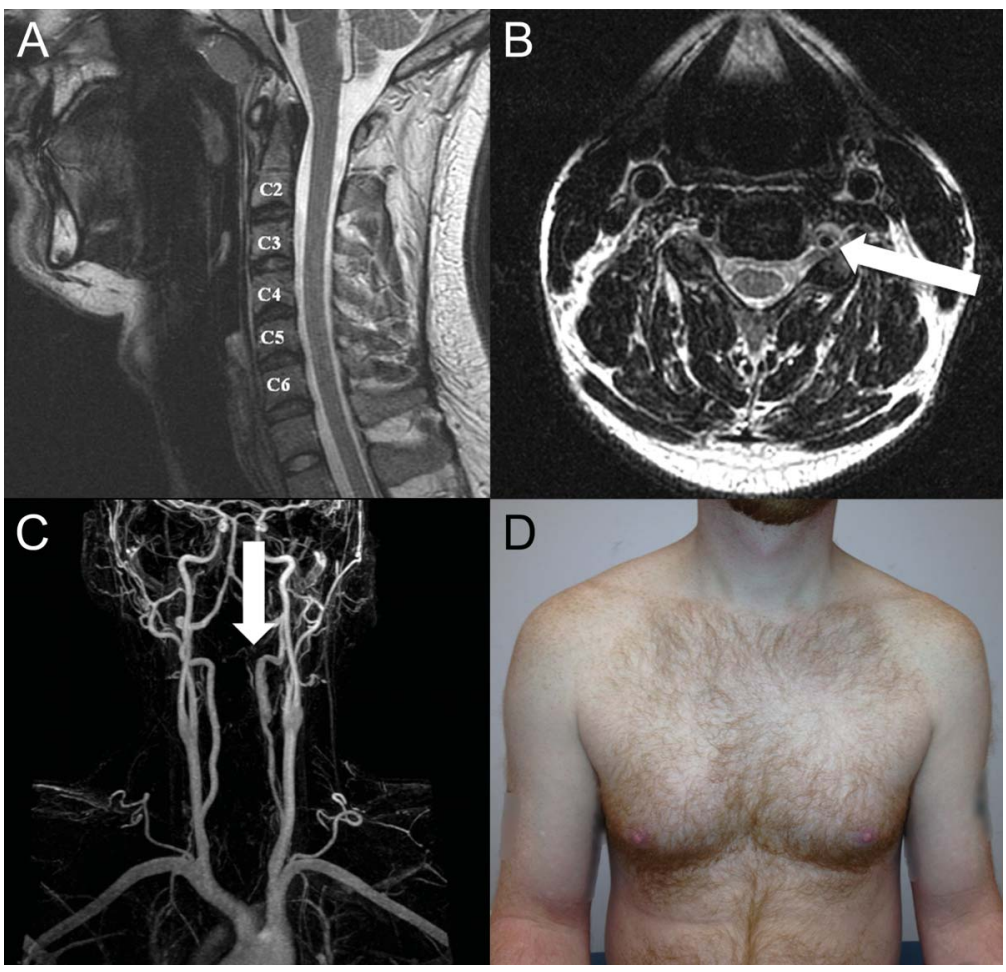

(A) MRI T2 sagittal view demonstrates absence of significant disk herniations. (B) Axial cut from just above the C5 vertebra demonstrates impingement of the root by the vertebral artery. (C) Magnetic resonance angiography demonstrates a large expansile left vertebral dissection. (D) Atrophy of the left deltoid and biceps. (Potentially identifying tattoos have been blurred.)

A 32-year-old mechanic developed severe left neck pain at work. Two days later, he experienced left arm weakness, particularly shoulder and elbow flexion; after another 2 days, he noted numbness at the left jaw angle. Examination revealed weakness in the C5 myotome and absent biceps reflex, but no facial or jaw numbness.

Brain MRI was unremarkable. Cervical MRI revealed no disk herniations (figure, A); however, a large left V2 vertebral artery dissection was noted compressing the C5 nerve root (figure, B). Magnetic resonance angiography (figure, C) and CT angiography confirmed an intramural hematoma with a dissection flap from C4-C2. EMG and neuroexamination 1 month later revealed a subacute C5 radiculopathy and atrophy in the C5 myotome (figure, D).

Colin Quinn, MD, Johnny Salameh, MD

From the University of Massachusetts Memorial Medical Center, Worcester.

Author contributions: Dr. Colin Quinn: conceptualization and design of the study and drafting the manuscript. Dr. Johnny Salameh: conceptualization of the study and revising the manuscript for intellectual content.

Study funding. No targeted funding reported.

Disclosure: The authors report no disclosures relevant to the manuscript. Go to Neurology.org for full disclosures.

Correspondence to Dr. Quinn: colincq@gmail.com 


\section{Neurology}

\section{Vertebral artery dissection causing an acute $\mathrm{C} 5$ radiculopathy \\ Colin Quinn and Johnny Salameh \\ Neurology 2013;81;1101 \\ DOI 10.1212/WNL.0b013e3182a2cc27}

This information is current as of September 16, 2013

\section{Updated Information \& Services \\ Subspecialty Collections}

Permissions \& Licensing

Reprints including high resolution figures, can be found at: http://n.neurology.org/content/81/12/1101.full

This article, along with others on similar topics, appears in the following collection(s):

\section{All Spinal Cord}

http://n.neurology.org/cgi/collection/all_spinal_cord EMG

http://n.neurology.org/cgi/collection/emg

MRI

http://n.neurology.org/cgi/collection/mri

Information about reproducing this article in parts (figures,tables) or in its entirety can be found online at:

http://www.neurology.org/about/about_the_journal\#permissions

Information about ordering reprints can be found online: http://n.neurology.org/subscribers/advertise

Neurology ${ }^{\circledR}$ is the official journal of the American Academy of Neurology. Published continuously since 1951 , it is now a weekly with 48 issues per year. Copyright @ 2013 American Academy of Neurology. All rights reserved. Print ISSN: 0028-3878. Online ISSN: 1526-632X.

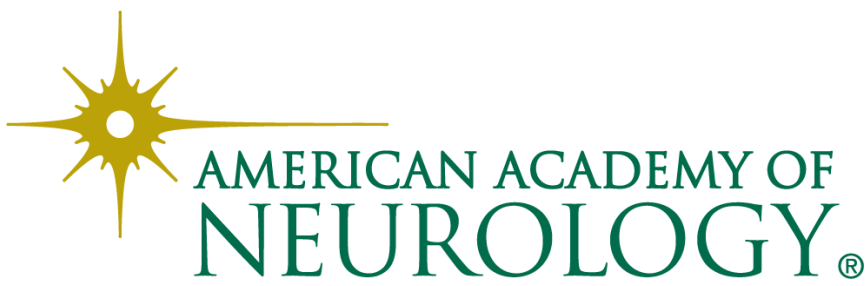

